Doi: https://doi.org/10.31578/jebs.v6i1.226

\title{
Reflections of Policies Related to History Education and Culture during Atatürk's Period in Samsun Press*
}

\author{
Pelin İskender Kılıç**
}

\begin{abstract}
The cultures and civilizations having their roots in the past form the basis of states. The basis provided during the establishment of the Republic of Turkey has shown itself also in the process of creating a national identity. This also means returning to its historical past, revealing the main elements of its culture with social engineering and putting it into practice. In this period during which the understanding of national history was adopted, the Turkish Historical Society (TTK) and the Turkish Language Institute (TDK) were opened, Turkish History Congresses were organized, history departments of universities were established, and history teaching programs and books were reorganized at all levels of national education. This study focuses on the reflections on the policies related to culture, history and history education during Atatürk's period in the Samsun press. In the article, Ahali Newspaper, which started its publication life in Samsun in 1917 and continued its existence in the first years of the Republic, has been examined. It has been recorded that many articles related to both education and teaching, and also history and history education reflecting and supporting the policies of the period were published in Ahali Newspaper between the dates of 1932 and 1938.
\end{abstract}

Keywords: culture, history, history education, press, Ahali Newspaper, Samsun.

\section{Introduction}

More than a hundred newspapers and magazines were published in many cities of Anatolia and Istanbul both during the National Struggle and in the first years of the Republic. While the articles supporting the National Struggle and the Republic regime and policies were written in some of these newspapers, the articles not supporting or criticizing them were written in some other sources. During this period, the print media was of great importance as a means of forming public opinion. The support of the press was needed to ensure that the reforms were especially explained to the public and these were adopted by them. For this purpose, Mustafa Kemal Pasha asked for their support in meetings with journalists, one of which was held in İzmit on 16-17 January 1923 and the other in İzmir on 4-5 February 1924 (Bayındır Uluskan 2010, p. 122-123). In this period when the Turkish Revolution was trying to adopt the approach to education in general, and history and history education in particular, as requirements of state policy were examined in the sample of Ahali Newspaper within the framework of the local press of Samsun. When the articles published in Ahali Newspaper have been examined, it was understood that it fully supported the National Struggle and the reforms and the republican regime carried out also after the success of National Struggle, as included in the purpose of its establishment.

\footnotetext{
" It is an extended version of the article presented at the International Learning Teaching and Educational Research Congress (6-8 October 2018, Amasya).

"Dr. Ondokuz Mayıs University, Faculty of Education, Department of Turkish and Social Sciences Education - Samsun/Turkey
} 
Ahali Newspaper started to be published in Samsun in 1917 (T.C. State Yearbook 1926-1927: 783). In a copy of the newspaper dated 29 October 1932, this was stated under the heading "Our newspaper celebrates its $15^{\text {th }}$ year". It was first published once a week on Thursdays, and later twice a week. Ahali Newspaper was a Turkish newspaper which was published to advance the country and inform the public (Güner \& Kabataş, 1990, p. 314). Under its name on the first page of the newspaper, there was a statement "It is a Republican, Populist Weekly Country Newspaper". İsmail Cenâni Bey was the owner and manager of the newspaper, which was printed in the Vatan Printing House as 400-500 copies (Kocaoğlu, 1999, p. 155). After graduating from Samsun High School, İsmail Cenanî Bey went to Istanbul for higher education. However, he could not continue his education due to the troubled days of the country, so he returned to Samsun, and then established a small but modern printing press (Coşar, 1964, p. 242, 250). In the newspaper, the articles were written to ensure national unity and solidarity and to support national resistance against the Pontus gangs being active in the Black Sea Region. İsmail Cenanî Bey secretly obtained detailed information about the murders of the Pontus gangs in Samsun villages and the name lists of the Turkish villagers murdered by them from the gendarmerie commander and later he published them. Thus, by informing the public in Samsun, he attracted their attention to what was going on and encouraged them to struggle. For this reason, the newspaper was frequently closed by the British occupation forces commander. Lawyer Mehamî Mehmed Aziz Bey and Teacher Kemal Bey were editorial writers. The publication of the newspaper, which was printed consisting of six pages since 29 October 1932 (Ahali, 29 October 1932), continued at intervals until 1944 when İsmail Cenanî Bey passed away. In the last years of the National Struggle, the supplements were released under the name of Ahâli Mecmuâ-ı Edebesi (Coşar, 1964, p. 244, 245, 250).

Change and innovation activities beginning with the establishment of the Republic of Turkey showed its effect also in the field of history as in all fields. The desire to create a national identity brought the understanding of national history writing in its wake and so the interest and perspective toward history took a completely different view. Enver Ziya Karal stated that Atatürk's studies on history were the continuation of the War of Independence in the field of culture. He emphasized that these studies were carried out to get rid of the foreign history views developed against the detriment of national history both inside and outside the country and to reveal the true character of Turkish history. In this regard, by establishing the Turkish Historical Society (TTK) in 1930, the studies became more systematic and thus, they progressed more rapidly (Karal, 1945, p. 2). Right after the establishment of the Turkish Historical Society (TTK), the first Turkish History Congress was held in 1932 and then the second Turkish History Congress in 1937. These congresses aimed at encouraging the researches related to Turkish history based on the past and at revealing the contributions of Turks in the field of civilization. Both congresses were extremely important in terms of promoting the Turkish history theses domestically and abroad (Pala, 2008, p. 80-81).

Benefiting from newspapers to create citizen identity is a method also seen in different countries around the world. For a long time, scholars have pointed out the important role that the newspapers and news media play in the development of national identities (Lieberman \& Miller, 2020, p. 2). Developing citizen identity was emphasized especially since the establishment of the United States of America, and various policies and methods related to this have followed. One of these methods is the use of newspapers. Accordingly, some educators argued that mass media had an impact on the education of citizens as much as they could reach large masses of people, and stated that newspapers emerged as a result of a historical process (Park, 1923). Lawrence A. Cremin (1988) studied the place of the press in public education in the late 18th and the 19th century. He argued that the steady population growth on the American border and the development of civilization in the period, which is today called the early national era, were parallel to the establishment of newspapers, news-gathering, and transmission activities. Cremin (ibid) believed that educational organizations and tools included schools, colleges, and universities, as well as newspapers and journals. Mass media which is an indispensable element of human life today is a part of formal or non-formal education. Therefore, research into the effects of the program "Newspapers in Education" cannot be disconnected from research into civic education (Claes and 
Quintelier, 2009, p. 343). Newspapers have gradually become an important tool in strengthening education, especially history education. They have played an important role in corroborating citizens' knowledge of both their history and also their belonging to citizenship.

\section{Method}

The model used in this study is document review. This is a broad time-based analysis of the documents produced within a given time frame about a research problem or by multiple sources on the relating subject and at different intervals (Yıldırım \& Şimşek, 2005, p.187-188). During Atatürk's period when the Turkish Revolution occurred, an effort was made to examine to what extent that approach to history and history education under the state and the decisions taken in Turkish History Congresses were reflected in Samsun local press. In the study, the copies of Ahali Newspaper that we could reach between the dates of 1932-1938 have been studied. As for the number of newspapers, the issues starting from 550 to 771 have been examined. History and history education are included in them and the news on education and culture in this context constituted the focus of the research. In total 107 copies of Ahali Newspaper have been examined. Since the Latin letters were newly accepted, there were some spelling mistakes in the news. But these have been corrected. For example, Kamal Ata Türk has been corrected as Kemal Atatürk or 15 th, as $15^{\text {th }}$.

\section{Findings}

The findings have been obtained as the result of the chronological examination of the copies of Ahali Newspaper that its beginning was accepted as 1932 in which the Turkish Historical Society was founded and its end date as 1938 which is Atatürk's date of death. News about history education and culture has been classified. While evaluating the findings, it has been taken into consideration whether there was a reflection of Turkish History Theses in the news according to the general policy of the period, what is mainly focused on the issues related to history education and culture, and which period of Turkish history is mostly emphasized.

\section{Educational and Cultural Studies}

When the copies of Ahali Newspaper have been examined, it can be said that the newspaper undertook an important mission regarding educational and cultural activities. There was much news related to this subject. Samsun Community Centre opened courses in various fields, among which such courses as Homeland Information, Civil Information, Economic Information, Peasantry, the Cooperative System, Banking, French, German, English, Calculating, Accounting and machine writings were included (Ahali, 31 May 1932).

In the copies of Ahali Newspaper in September, there were generally articles about opening schools, school enrolments, and the features of schools (Ahali, 13 September 1932). In September when the schools were opened, the books, clothes, lunch and other food aids by the "Patronage Committees" to the orphans and the children from financially not well-off families were mentioned (Ahali, 20 September 1932). Various investigations were made to open a secondary school in the district of Bafra (Ahali, 12 September 1933). Village schools and teachers were paid a great attention to during this period. There were articles in various copies of the newspaper on this subject (Ahali, 8 August 1933; 4 June 1936; 11 June 1936; 25 June 1936; 9 July 1936; 30 July 1936). In the news it was emphasized that not only education, but also health services were extremely important in village schools. A long article on the subject under the title of "Healthcare Work in the Village Schools" was written by A. İhsan for Dr. Reşit Galip 
Bey, Minister of Education. In this article it was underlined that the health of school-age children, especially the ones in the village, in Turkey where there were forty thousand villages and tens of millions of peasants, should be given importance. It was stated that these children would be the guardians of tomorrow, valuable brains of university chairs, and precious masters of the factory bench. It was indicated that if the health of these children was not paid attention to, the country would be deprived of them and this would lead to very serious consequences. Regarding this issue, the examples were given from England and especially the United States of America. It was underlined that the diseases, especially related to the ears, eyes, teeth, and tonsils, created barriers to reading and learning, and so the necessary precautions should be taken (Ahali, 8 August 1933). Moreover, an exam was held on September 10 for the teachers who would go to America for the education of the public and peasantry, and Fehmi Yekta Bey and Fikret Bey from Samsun held the exam. The questions were about the education of the peasantry and the public (12 September 1933).

In the article entitled "The value of the work of the village's children is the force of the Republic of Turkey", the importance of village schools was emphasized, and also it was underlined that they should be applied to business schools. It was stated that knowledge, which was not useful to the child in business life with intense and tiring programs, was nothing more than a useless ornament, and this would not benefit the child and his/her family. It was argued that knowledge which would be useful for the child should be given in the future instead of that, and also it should be related to the vineyard, garden, farm, necessary actions to be done to get good products and livestock. Besides, it was mentioned that knowledge about motherhood and child care should be given to girls to minimize the mortality rate in the village (Ahali, 5 July 1932).

Under the title of "Lesson Time", the article of T. Fikret Bey, who was the teacher in the village of Çukurbük, was published. In the article, Fikret Bey stated that he started the lesson with twenty-four students, eight of whom were girls and sixteen were boys, the school was repaired and the desks were built, and the children were taught manners and rules to be followed. It was expressed that the lesson was started, one and a half months passed with games and songs, and the children were very interested in learning and school. As it is understood from the article, the style and attitude of the teacher towards children are very kind (Ahali, 11 July 1932).

Another educational activity reflected in the newspaper is related to the activities of the "Turkish Folklore Association" given under the title of "A review experience concerning our last ten years of folklore activity and publication". The association was active in Ankara, Erzurum, İstanbul, İzmir, Kayseri, Konya and Samsun. In its 25-item regulation, its aim was stated: "to analyze Turkish folklore and culture; to publish magazines, newspapers, and books; to organize conferences, events, and travel; to be in contact with other similar scientific societies". According to the news published in the newspaper, it was a folklore association carrying out serious research and gathering activities of Turkish folk music and accepting purely scientific procedures as a guide while doing these (Ahali, 9 August 1932, 10 July 1934).

In this period when the Turkish history theses was put forward, there were attempts to investigate the origins of Central Asian Turkish History. Interest in Turks and Turkish culture increased. In 1930, the work entitled "Outlines of Turkish History" was written by some of the members of the Turkish History Delegation upon the order of Atatürk. It is possible to see the articles about this in various copies of Ahali Newspaper with different dates. The magazine and its features, which had the same name under the title of Azerbaijan Homeland Information and were published every month, were included in a copy of the newspaper. It was mentioned that it was an extremely valuable scientific journal and contained important articles (Ahali, 15 November 1932).

An article entitled "Old Turkish Religion-1", which was about Pre-Islamic Turkish History, and the author of which was mentioned as Abdülkadir, was published on the culture page. In this article written in three columns, Shamanism, the Altai Mountains, the Mongols and the traditions of the Turks were stated. Further, Ceyhunî, who is one of the $19^{\text {th }}$-century folk poets, 
and his poems were included in the article by M. Şakir (Ahali, 23 January 1934; 6 February 1934). In the second part of the article about Old Turkish Religion, the subject of "Where the Old Turkish Religion Lives Today" was discussed. Here, many rivers, lakes and mountains, and the communities of Telengit Turks, Kyrgyzs, Chernovoy Tatars, White Kalmyks, Altay Kiji, Töles, Teleuts, Chuvashes, etc. living in these regions were mentioned. Besides, the number of Shaman Turks was given. The third part of the article written under the title of "Old Turkish Religion" was prepared under the subtitle of "General Comments on Shamanism". Here, the subjects such as shamanism itself, its history and characteristics, whether it was religion or not, the view of China and Russia, and its current situation were discussed (Ahali, 27 February 1934). This subject continued under the same subtitle in the next copy of the newspaper. In the fourth part, the subjects such as the corruption of shamanism, the effect of newly accepted religions, how the subject of religion was in Orkhon inscriptions, the relationship between the religions of Buddhism and Manichaeism and the Turks, where shaman culture has prevailed, were included (Ahali, 13 March 1934). In the $5^{\text {th }}$ part, shaman culture was considered as a religion. It stated that the revelation was communicated through a fourteen-year-old girl. Accordingly, people should worship on their knees three times a day, that is to say, in the morning, at noon and in the evening. While preparing for worship, the beech tree should be decorated with ribbons. It then compared this belief expressed as Turkish religion to the heavenly religions and focused on narrations (Ahali, 3 April 1934).

Another issue addressed in the Turkish History Congress was the Turkish language and the origin of the Turkish language. Many articles were written in the newspaper on this subject. Based on the language issue, an effort to cover some periods of Turkish history were made. In the context of cultural studies, the writer, M. Şakir, who was in Maraş in 1915, described his impressions under the title of "A Compilation Memory" in the newspaper. Here, he discussed issues of folklore. He recorded the traditions, the clothes, the words spoken in the folk language related to Maraş culture, and collected folk songs and folk poems. He pointed out that this place was a completely Turkish region, and there should be extensive studies on national history, ethnography, and culture (Ahali, 22 November 1932). This subject was also addressed in later newspaper news. As it is understood, language being one of the important elements of culture has an important place in the cultural policies of the newly established state, just like the science of history, and it was reflected in the local press. This subject was later rewritten by M. Şakir. The news was published under the title of "Word Compilation Job". In the news, it was stated that some people in the entire country, especially in the intelligent group, were closely and actively engaged in searching, finding and revealing important aspects of the language is an important and national duty. It was also stated that these researches were carried out in a very careful and scientific manner. It was pointed out that a study was carried out in Ahali Newspaper to form the Provincial Word Compilation Central committee, and the Compilation Decree was issued. These studies in the newspaper were declared as "the last link of valuable revolution, the most important issue of the day, the greatest essence of a whole nation is the language itself." It was said that "it is comprehensive enough to involve all layers of people without exception, and this movement is exciting enough to bring the whole country closer" (Ahali, 27 December 1932). Later on, a column was reserved in the newspaper under the title of "Language Column" and here the meanings of various words were given with their descriptions. Proverbs were sometimes described in various columns (Ahali, 10 July 1934; 21 August 1935; 10 September 1936). On the first page of the newspaper, an article about the Language Festival was published, and poems were included under the subtitle of "Turk! Protect Your Language, Know Yourself" under the title of "The Union of the Nation is Established with the Language Union" (Ahali, 26 September 1934; 24 September 1936).

After S.M. Kazım, a teacher from Samsun, specified what yearbook was and its properties in his article entitled "Our Hometown in Trabzon Yearbook", he transferred the sections about Samsun in the Trabzon Provincial Yearbook (Ahali, 30 January 1934). The series of articles continued for a few months under the same title (Ahali, 20 March 1934). By mentioning the history of Trabzon and Samsun under the title of "Faraway History", he talked about The Kingdom of Pontus and the Amazons (Ahali, 10 
April 1934). It was mentioned that the Amazons were from Scythian Turks; Hittite women were also more likely to be from them. The article also explained what the old names of Samsun were; who conquered Samsun throughout history and what the conquerors built-in Samsun (Ahali, 17 April 1934; 8 May 1934). In the continuation of the article series, information was given about the population of Canik Sanjak. After giving the numbers of districts, sub-districts, villages, and neighborhoods of Samsun, populations of the center, districts, and sub-districts were transferred (Ahali, 10 July 1934). In the following weeks, educational activities at the Canik Sanjak were mentioned. It was stated that there were 651 elementary schools for Turkish children and 12.298 students attended those schools. The number of schools and students was given according to the towns (Ahali, 24 July 1934). In the continuation of the article series, the appearance and personality traits of the people of Canik, their customs, accents, and deceases such as malaria, etc. were mentioned. Soil features, geographical locations, rivers, and grown crops were also reflected (Ahali, 11 September 1934). By continuing the same subject in the next copy, the number of fountains, baths, taverns, and casinos located in the center and districts was included (Ahali, 2 October 1934).

As another cultural movement, it was stated that under the title of "Everyone Will Bear a Turkish Name", it was accepted and signed that all community members should bear Turkish names at the general meeting of the Language, Literature and History Branch in Samsun Community Centre (Ahali,15 May 1934). In the article entitled "Why is a Surname Necessary?", by mentioning that the old Turks gave importance to their surnames, but this was later forgotten (Ahali, 28 June 1934; 11 June 1936; 18 June 1936).

In the article entitled "Army of Science and Youth in the Republic" by lawyer M. Kamil Bey, Bar President concerning the issue how Germany became a strong country in every field due to education was explained in detail with examples from the world history. He mentioned that teachers should have goals like raising children and the youth of the country with the pride of patriotism, instilling the love of the republic into their souls, reanimating the homeland and raising it full of savior ambitions. He emphasized that children who were educated nationally in primary school should always aim at taking the country further while they were studying in secondary school, high school, and university. He put forward the idea that young people who grew up in this way should go to the villages and contribute there to raising the precious village children of Anatolia, who would continue the love of the Republic there because the cornerstones of the Republic were in the children of the country with a strong mind and robust body (Ahali, 24 July 1934).

In the newspaper, a series of articles was started under the name of "History of Samsun, a Short History of Samsun and its Region". The writer was Dilcimen. According to the writer's statement, the series of articles where the translation of the Greek book written and published by H.Papa Yorgiyadis in Athens in 1891. This translation was done by Pavlâki Y. Melitopulos, who graduated from the Faculty of Letters of Istanbul University. Again, according to the writer's statement, this person wrote many works to spread Turkish culture, and in 1935 he printed a Turkish - Greek Dictionary. The writer stated that the book of History of Samsun by this person was more scientific than the work Past, Present, and Independence of Samsun by the French consul in Samsun. He informed that this French book by Vadala in Paris would be presented to readers again in Ahali Newspaper. The author expressed the idea that he only mediated this by offering the translation of both works. The article began under the title of the "Prehistoric Age" and continued under the title of the "Mythology Age". In the article, the Prehistoric Age started with the period of Assyrian State in 2000 BC. Herodotus, Greek historians, Persians, and Scythians were mentioned in it. In the Mythology Age, Amazons and their features were explained (Ahali, 1 January 1936). Following week, in the $2^{\text {nd }}$ part of the article, it was mentioned again about the Amazons, their origins and their wars (Ahali, 8 January 1936). In the $3^{\text {rd }}$ part, the Age of Milaslılar ${ }^{26}$ was explained. After a long description of the inhabitants of Milaslılar and their struggles, it was stated that they dominated the

${ }^{26}$ Those living in the city of Milas. 
coastal area and established the old Samsun and also turned this place into a center of civilization against the barbarian tribes around (Ahali, 15 January 1936). In the $4^{\text {th }}$ part, while presenting the history of Samsun, the activities of Iran, the cities of Pontus and their features, and the struggles with the Lydians were discussed (Ahali, 23 January 1936). Later the same subject continued, and it was stated presented how the Iran-Athens struggle was, how the Athenians dominated the region, how they attached importance to this place by giving Samsun the name "Pirea", and also, how they put money in circulation by printing this money, on one side of which was an eagle, and on the other side the word "Pirea" (Ahali, 6 February 1936). In the $6^{\text {th }}$ part it was stated that a revolt broke out in the region of Samsun also with the influence of Iran, and Athens saw this revolt very dangerous for them because they bought wheat from this region. The work Anabasis by Xenophon was mentioned, and some of the information in this work was transferred (Ahali, 19 February 1936). In this section, the information by Xenophon continued. Later, the dominance and expeditions of Alexander the Great in the region were discussed under the title of "General Freedom" (Ahali, 12 March 1936). In the $8^{\text {th }}$ part, it was stated that Eupator Dionysos, King of Pontus, transferred his headquarter from Sinop to Samsun, after emphasizing Samsun and its importance in the period of the Roman Empire. Later, the period of Mitridat and the relations with the Romans were explained (Ahali, 19 March 1936). In the $9^{\text {th }}$ part, the wars and domination struggles of this period continued, and the siege of Samsun was described (Ahali, 7 May 1936). In the $10^{\text {th }}$ part, the Pontus and Roman struggle were viewed. Here, especially the strategic importance of Samsun was revealed (Ahali, 4 June 1936). In the $11^{\text {th }}$ part, the activities that Pompeius carried out were enumerated, it was described how Samsun was self-administered under the rule of the Romans at that time, how Pontus elements captured Samsun under the leadership of Farmakis II, and for this reason, how Julius Caesar advanced towards Farmakis and made him suffer a severe defeat and returned Samsun again under the Roman rule (Ahali, 25 June 1936). In the 12 part, it was mentioned that after Caesar, Samsun was a separate republic. Then, under the subtitle of "Christianity" it was presented when and how Christianity spread in Samsun (Ahali, 9 July 1936).

\section{Conclusion}

While the National Struggle continued, Mustafa Kemal Pasha, who gathered the First Education Congress in Ankara on July 1521,1921 , was aware that education was very important for the foundation of a new and modern state. In the opening speech of the congress, he described the educational approach of the new Turkish State as creating a culture which was independent of foreign influences, completely in line with its national character and historical background. In this period, a common Turkish culture and Turkish identity were tried to be created throughout the country. Therefore, the vast majority of innovations in the field of education were aimed at creating this common culture. For this purpose, the basics of Turkish culture were addressed and the studies started in the fields of language, history, and geography, which are the three most important elements of culture. Accordingly, the Faculty of Languages and History-Geography was established in 1935. Special attention was paid to history research, education and training. Atatürk regarded history as a serious and important branch of science that was necessary for the creation and continuity of a culture of society. If a state and nation wanted to survive, every individual had to have a deliberate historical consciousness which can and should be taught. Hence, Atatürk's interest in history was not random. This attitude shown since the National Struggle period was maintained in a more systematic and planned way, especially since the 1930s. Turkish History Theses were reflected in primary and secondary education, the changes were made in this direction from time to time in the curriculum and history textbooks were prepared accordingly. All kinds of activities were included by the state not only in the center, but all over the country, and this education and culture movement was supported. Locally in the Samsun press, when viewing from the sample of Ahali Newspaper, it was determined that both the writings by the Turkish History Theses and national holidays and all kinds of cultural activities in this direction were included with great importance and meticulousness. 
Atatürk said: "Culture is the foundation of the Republic of Turkey". He saw the continuation of the National Struggle as a cultural issue. Therefore, in the first years of the Republic, great importance was attached to educational and cultural studies, and a great mobilization was initiated across the country in this regard. Most of the studies in history were used to get to the root of Turkish culture. This mobilization that was started across the country had an inevitable reflections on Samsun press. When the copies of Ahali Newspaper were examined, it was seen that there was much information related to culture and education, and these issues were always in the context of history. As far as it could be determined, the villages were also attached special importance in educational and cultural activities. Children, especially village children, formed the focus and strength of the education and culture movement. Also, researches were held on the subject of language, which is an important part of the culture, and the subjects of Central Asian Turkish history and culture, which are the origin of Turkish culture and nation, had an important place in the newspaper. Some articles continued for a few weeks regarding Samsun's history and culture. All these publications had an outstanding educational impact on both young and adult people. 


\section{References}

Ahali Newspaper (1932-1938), Samsun.

T.C. State Yearbook (1926-1927). Matbuat-ı Müdüriyet-i Umumiye, İstanbul.

Bayındır Uluskan, S. (2010). Atatürk'ün Sosyal ve Kültürel Politikaları. Atatürk Kültür, Dil ve Tarih Yüksek Kurumu Atatürk Araştırma Merkezi, Ankara: Korza Basım

Claes, E. \& Quintelier, E. (2009). Newspapers in education: A critical inquiry into the effects of using newspapers as teaching agents. Education Research, 51(3), 341-363.

Coşar, Ö.S. (1964). Milli Mücadele Basını. İstanbul: Gazeteciler Cemiyeti Yayınları No.5.

Cremin, L.A. (1988). American education: The metropolitan experience, 1876-1980. New York: Harper \& Row.

Güner, Z. \& Kabataş, O. (1990). Millî Mücadele Dönemi Beyânnâmeleri ve Basını. Ankara: Atatürk Kültür Merkezi Yayını. Sayı: 38.

Karal, E.Z. (10.11.1945). Atatürk ve Türk Tarih Tezi. Ulus Gazetesi.

Kocaoğlu, B. (1999). Millî Mücadelede ve Cumhuriyet'in Illk yıllarında Samsun'da Basın Hayatı ve Cemiyetler. Ondokuz Mayıs Üniversitesi Eğitim Fakültesi Dergisi. Sayı: 12/1, 155-160.

Lieberman, E. \& Miller, A. (2020). Do online newspapers promote or undermine nation-building in divided societies? Evidence from Africa. Nations and Nationalism. Wiley Online Library, 1-22. Retrieved October 24, 2020.

Pala, K. (2008). Atatürk Dönemi Türk Tarih Kongreleri. Yüksek Lisans Tezi. Samsun: Ondokuz Mayıs Üniversitesi.

Park, R.E. (1923). The natural history of the newspaper. The American Journal of Sociology, 29 (3), $273-289$.

Yıldırım, A. \& Şimşek, H. (2005). Sosyal bilimlerde nitel araştırma yöntemleri. Ankara: Seçkin Yayınları. 